\title{
Antioxidant and Anticancer Roles of a Novel Strain of Bacillus anthracis Isolated from Vermicompost Prepared from Paper Mill Sludge
}

\author{
Ram Kumar Ganguly iD, Sujoy Midya, and Susanta Kumar Chakraborty \\ Department of Zoology, Vidyasagar University, Midnapore 721102, West Bengal, India \\ Correspondence should be addressed to Ram Kumar Ganguly; ramkumarganguly10@gmail.com
}

Received 13 March 2018; Revised 3 July 2018; Accepted 7 August 2018; Published 26 August 2018

Academic Editor: Richard Tucker

Copyright (C) 2018 Ram Kumar Ganguly et al. This is an open access article distributed under the Creative Commons Attribution License, which permits unrestricted use, distribution, and reproduction in any medium, provided the original work is properly cited.

\begin{abstract}
Mass production of vermicompost using suitable species of earthworms and selecting target organic waste materials has appeared to be a great development in the realm of biotechnological research for the sustainable eco-management. Although, for the bioconversion of organic wastes to vermicompost, suitable earthworm species play major roles, a hoard of bacterial assemblages by virtue of production of different enzymes facilitate the process of vermicomposting. The present study has documented the roles of vermicompost associated bacteria in combating, preventing, and controlling of cancer so as to open a new vista not only in the field of vermitechnology but also on biomedical research. Earthworms' associated bacterial metabolic products having their unique physicochemical excellence have gained importance due to their roles as a facilitator of apoptosis (programed cell death in a MCF-7 cell line). The antioxidant and anticancer activities of ethyl acetate extracts' of vermicompost associated bacterium Bacillus anthracis were undertaken by antioxidant assay which revealed maximum DPPH radical scavenging effect $(75.79 \pm 5.41 \%)$ of the extracts' at $900 \mu \mathrm{g} \mathrm{ml}-1$. Furthermore, the crude extracts obtained from the same bacteria were found to decrease the activity of SOD (superoxide dismutase) with the increase in doses. MTT assay showed potent cytotoxic activity against human breast adenocarcinoma cells (MCF-7) with the IC50 value of $46.64 \pm 0.79 \mu \mathrm{g}$ ml-1. It was further confirmed through Hoechst 33258 staining of nuclear fragmentation assay and DNA fragmentation analysis. Western blotting test has confirmed a downregulation of Akt upon application of crude extracts. Increase of SOD activity along with decrease of Akt level reflects that the mode of action is entirely PI-3K dependent. This study tends to indicate that $B$. anthracis isolated from vermicompost could be potentially explored for the development of new therapeutic agents, especially against cancer.
\end{abstract}

\section{Introduction}

Vermitechnology involving vermiculture and vermicomposting process has emerged as a highly suitable, user-friendly, and cost-effective eco-technology for proper organic waste management [1]. During vermicomposting, nutrients such as nitrogen, carbon, potassium, phosphorus, zinc, and calcium of waste materials while passing through the earthworms gut are homogenized in bacterial rich environment into a highly mineralized chemical forms which are much more available to the plants when used as fertiliser [2]. It is a decomposition process in which biochemical degradation of the of organic waste materials as substrate occurs by the joint action of earthworms and microorganisms by way of fragmentation, conditioning, and stabilization [3]. Although the process involves microbial degradation, earthworms are the actual drivers of this technology $[4,5]$.

The present study has attempted to highlight a new vista on roles of these microbes in the context of health science. Microorganisms have so far established their importance in combating several medical problems through the production of several bioactive compounds for therapeutic purposes [6, 7]. Each year millions of people are diagnosed worldwide with cancer, and more than half of these patients eventually die from this disease. Based on global cancer statistics published in the year 2011, 12.7 million cases of cancer were detected and 7.6 million cancer deaths in a year were reported $[8,9]$. Conventional cancer treatments 
such as surgery, chemotherapy, and radiotherapy often fail to achieve a complete cancer remission. Moreover, it has been widely recognized that radiotherapy or chemotherapy is likely to cause significant side effects [10]. This fact has prompted to undertake more researches for the development of patient-friendly new approaches for the treatment of cancer. Microbial based therapy of cancer is one of the emerging cancer treatment modalities [11]. Important advances have been made to study and develop live bacteria or bacterial products such as proteins, antioxidant enzymes, immune toxins, and secondary metabolites which specifically target cancer cells and cause tumor regression through growth inhibition and arresting of cell proliferation in order to arrest and retard apoptosis induction [12, 13]. Recently, many studies have focussed on and recommended the anticancer property of bacterial metabolites of Clostridium, Bifidobacterium, Listeria, Salmonella, Lactobacillus, Escherichia, etc. $[14,15]$.

In such context, the present study has opened up a new vista towards the utility of vermicompost as a potential incubator for some beneficial bacteria which not only trigger and accelerate the process of vermicomposting but also paved the way of utilizing them as anticancer agents.

\section{Materials and Methods}

2.1. Collection of Sludge. Sludge sample was collected in plastic bags from UNIGLOBAL paper mill at Jhargram, India $\left(22^{\circ} 27^{\prime} 0^{\prime \prime} \mathrm{N}, 86^{\circ} 59^{\prime} 0^{\prime \prime} \mathrm{E}\right)$ under aseptic conditions. Samples after being processed and sundried were used for vermicomposting.

\subsection{Experimental Design and Chemical Analysis. Sundried} samples after being properly grounded were mixed up with supplements such as cow dung and straws in a ratio of $5: 4: 1$ (ratio was optimized focussing on least mortality rate of earthworms) and were consumed and turned over by Eisenia fetida for a duration of 60 days. Sludge samples could not be used directly due to its toxic properties. The temperature during the entire process of composting was maintained at $25^{\circ} \mathrm{C}$ with a moisture content of around $60 \%$ and $\mathrm{pH}$ (7.4-7.8) through the regular sprinkling of water. All the experiments were performed in triplicate [16].

2.3. Growth of Bacteria and Preparation of Crude Extract. $1.0 \mathrm{gm}$ of the sample from vermicompost of each replicate was subjected to serial dilution up to $10^{-6}$ in normal saline solution. $200 \mu \mathrm{l}$ of the sample was added in nutrient broth (HIMEDIA) and kept at incubation for $48 \mathrm{~h}$ at $37^{\circ} \mathrm{C} .10 \mu \mathrm{l}$ of samples was taken and further spread over minimal agar plate made up of nutrient agar (HIMEDIA) and kept at incubation for $24 \mathrm{hrs}$ at $37^{\circ} \mathrm{C}$ for proper isolation of colonies [16].

\section{Identification of Bacteria}

3.1. 16srRNA Gene Sequencing and Phylogeny Construction. 16srRNA sequencing technique was used here for identification of bacterial isolates. Three heat shock cycles $(20 \mathrm{~min}$ at $-85^{\circ} \mathrm{C}$ and $15 \mathrm{~min}$ at $95^{\circ} \mathrm{C}$ ) were used for genomic DNA isolation. Amplification of DNA samples through PCR (polymerase chain reaction) was carried out using two universal primers 27F ( $5^{\prime}$-AGAGTTTGATCMTGGCTCAG-3 $\left.{ }^{\prime}\right)$ and 1492R (5'-AGAGCCCGATCMTGGCTCAG-3'). Sequencing of DNA sample was performed using ABI PRISM Big Dye TM Terminator Cycle Sequencing Kits with AmpliTaq DNA polymerase (FS enzyme) (Applied Biosystems). Single-pass sequencing was performed using 27F/1492R primers and fluorescently label fragments were purified and subjected to electrophoresis in an ABI 370X1 sequencer (Applied Biosystems) [16, 17].

16srRNA gene sequence was BLAST using NCBI BLAST search tool. MUSCLE 3.7 programs used for multiple alignments of sequence and were cured using program G blocks 0 . 91b. Finally, PhyML3.0Alrt was used for phylogeny analysis using HKY85 as substitution model and program Tree Dyn 198.3 was used for tree rendering [18].

3.2. Preparation of Crude Extract. Bacterial isolate was cultured in nutrient broth at $35 \pm 2^{\circ} \mathrm{C}$ for $72 \mathrm{~h}$ and then it was centrifuged at $10000 \mathrm{rpm}$ for $20 \mathrm{~min}$. Supernatant was collected and filtered using $0.22 \mu \mathrm{m}$ filter to remove bacterial cells. Cell free supernatant was allowed to mix with ethyl acetate in ratio of $1: 1$ and was concentrated using rotary vacuum evaporator. Crude extracts from the produced vermicomposts were obtained and used for further experiments [19].

\subsection{Antioxidant Activity}

3.3.1. DPPH Radical Scavenging Activity. The capability of crude extract to demonstrate antioxidant activity was determined through DPPH (1,1-diphenyl-2-picrylhydrazyl) radical scavenging assay [20]. Different concentrations (100, 300, 600 , and $900 \mu \mathrm{g} \mathrm{mL}^{-1}$ ) of extracts were prepared in distilled water. Ascorbic acid $\left(100,300,600\right.$, and $\left.900 \mu \mathrm{g} \mathrm{mL}^{-1}\right)$ was used here as positive control. $0.15 \mathrm{mM}$ of DPPH solution was added to both test sample and control. It was then vortexed for 5 minutes and allowed to stand for $20 \mathrm{~min}$ at room temperature in dark. Absorbances of the samples were measured in spectrophotometer (SHIMADZU; UV-1601) at $517 \mathrm{~nm}$. Radical scavenging activity was determined using the following equation: Scavenging effect $(\%)=[1-(A$ sample $-A$ sample blank)/A control] x 100

$A$ control is the absorbance of the control, $A$ sample is the absorbance of the extract, and $A$ sample blank is the absorbance of the sample only.

3.3.2. Activity Staining of SOD. Activity staining of SOD (Superoxide Dismutase) was performed using nondenaturing PAGE, followed by staining of gel. Protein from each sample was separated by $10 \%$ nondenaturing Polyacrylamide Gel Electrophoresis at $4^{\circ} \mathrm{C}$. After electrophoresis, the gel was soaked in $1.23 \mathrm{mM}$ NBT (Nitro-blue Tetrazolium) solution for $20 \mathrm{~min}$ in dark. The gel was briefly washed in distilled water and incubated for 15-20 min under dark in $100 \mathrm{mM}$ phosphate buffer ( $\mathrm{pH}$ 7.0) containing $28 \mathrm{mM}$ TEMED 


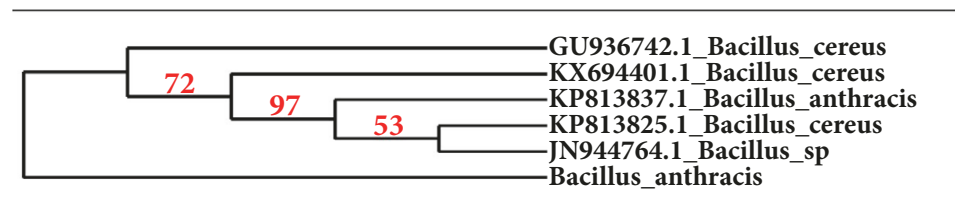

FIGURE 1: Phylogenetic affiliation of Bacillus anthracis.

(Tetramethylethylenediamine) and $0.28 \mathrm{mM}$ riboflavin. The gel was exposed to a fluorescent light until the appearance of clear zones of activity bands with blue background. Intensity of bands was analyzed by densitometry scanning using an Alpha Image Analyzer System (Alpha Innotech, San Leandro, CA, USA) [21].

\subsection{Anticancer Activity}

3.4.1. MTT Cytotoxicity Assay. The assay was used to determine the anticancer activity of crude extract over MCF7 (human breast adenocarcinoma) cancer cell line. Cells were grown as monolayer in DMEM-AT068 with necessary supplementation at $37^{\circ} \mathrm{C}$ under $95 \%$ humidified air and $5 \%$ $\mathrm{CO}_{2}$. In brief, cells at concentration of $3 \times 10^{3}$ cells per well were seeded in $100 \mu \mathrm{l}$ of complete medium with various concentrations $\left(50,100,150\right.$, and $\left.200 \mu \mathrm{g} \mathrm{mL}^{-1}\right)$ of crude extracts. After that $10 \mu \mathrm{l}$ of $5 \mathrm{mg}$ per ml MTT [3-(4,5-dimethylthiazol2-yl)-2,5-diphenyltetrazolium bromide] was added in each well for $3 \mathrm{~h}$ and was kept at dark. $100 \mu \mathrm{l}$ of DMSO was added after removing of media and absorption of formazan solution was measured at $570 \mathrm{~nm}$ using a microplate reader (ECIL). Cytotoxicity of the crude extract was measured as IC50 value (concentration of extract inhibiting $50 \%$ of cell growth) [22].

3.4.2. Hoechst 33258 Staining. Single cover slip was placed in each well of 6-well microtitre plate and subsequently monolayer of MCF-7 cell culture was trypsinized. The number of cells was adjusted to 50000 cells $/ \mathrm{mL}$ and $2.5 \mathrm{~mL}$ of cell suspension was added drop by drop on cover slip in each well. The control well contained only maintenance medium. The plates were incubated at $37^{\circ} \mathrm{C}$ in $5 \% \mathrm{CO} 2$ atmosphere [23]. After this, incubation media was removed and the cells were washed with PBS for two times. Staining was done Hoechst $33258(5 \mu \mathrm{g} / \mathrm{ml}$ in PBS) for 25 minutes and after extensive washing by PBS cells were visualized through fluorescence microscope (Motic) at 40X objective magnification.

DNA was extracted from MCF-7 cells. The liver cells were treated with 25 mMTris-HCl buffer ( $\mathrm{pH} 7.5$ ) containing $0.5 \%$ SDS, $0.5 \mathrm{mg} / \mathrm{mL}$ proteinase $\mathrm{K}$, and $5 \mathrm{mM}$ EDTA at $55^{\circ} \mathrm{C}$ for 1h. Methodology was followed according to Riebiero et. al. [24].

3.5. Western Blotting. Western blotting is often used to separate and identify proteins [25]. $60 \mu \mathrm{g}$ of protein sample was denatured in gel loading buffer in boiling water bath for 5 minutes. The samples were cooled on ice and loaded on $10 \%$ SDS poly-acrylamide gel along with protein marker. Electrophoresis was carried out at $15 \mathrm{~mA}$ in stacking gel and resolved at $30 \mathrm{~mA}$ in resolving gel. After electrophoresis, protein was transferred into PVDF membrane overnight at $4^{\circ} \mathrm{C}$ with constant power supply of $50 \mathrm{~V}$. Protein transfer was confirmed through Ponceau S staining. Then membrane was blocked in 5\% nonfat milk in PBS ( $\mathrm{pH} 7.4)$ for $2 \mathrm{~h}$ at room temperature. Blot was then incubated with primary antibody P-AKT ser 473 (1:1000 dilution) in 1\% BSA and $0.05 \%$ Tween 20 in PBS ( $\mathrm{pH} 7.4$ ) overnight at $4^{\circ} \mathrm{C}$. After three washes with 1X PBST for 5 min, blot was incubated with HRP conjugated secondary antibody (1:2500 dilution) in PBS ( $\mathrm{pH}$ 7.4) containing $1 \%$ BSA and $0.05 \%$ Tween 20 for 3-4 hours in rocker at room temperature. After washing with PBST ( $\mathrm{pH} 7.4$ ), immune reactive protein was detected using ECL super signal kit (Pierce Biotechnology Rockford, IL) on Xray film. Intensity of the band was analyzed by densitometry scanning. Relative densitometry values have been calculated after normalization with $\beta$ actin.

3.6. Statistical Analysis. Statistical analysis was performed by SPSS software using one-way analysis of variance followed by Tukey test. Pairwise T-test was made in comparing values of treated cells with respect to normal. Values are being expressed as mean \pm SEM obtained from different sets of experiments. Significance of the tests was considered with $\mathrm{P}$ value at $\mathrm{P}=0.05$. All the experiments were performed in triplicate.

\section{Results}

4.1. Isolation of Bacteria and Phylogenetic Affiliation. Different colonies of bacteria were isolated and upon 16srRNA sequencing they were found to be a strain of Bacillus anthracis. Previously, this bacterium was isolated from environmental sample like soil [Figure 1] [26].

4.2. DPPH Radical Scavenging Activity. Though there are many antioxidants available from plants and other food sources but antioxidants from bacterial sources due to their efficacies ruled out others [27]. DPPH radical is scavenged by antioxidants and is converted to reduced DPPH. Linear progression of activity in both experimental and control set-ups reflect that the extracts obtained from $B$. anthracis can perform as natural antioxidant with high efficiency. These findings have established the facts that extracts are 


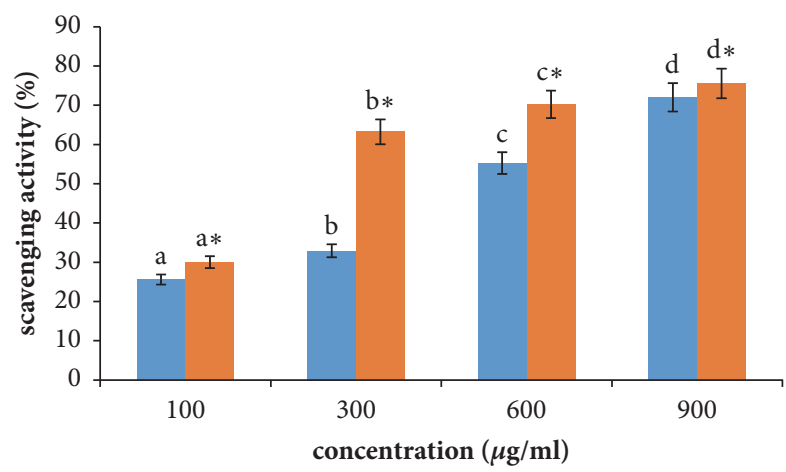

FIGURE 2: Effect of crude bacterial extracts on scavenging activity in control and treated MCF-7 cells. Results are expressed in terms of values representing mean \pm SD where $n=3$ at ${ }^{*} \mathrm{P}=0.05$.

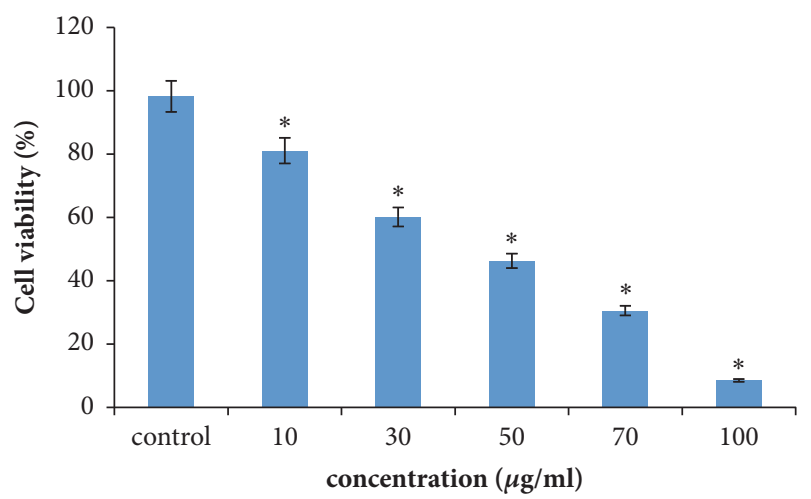

FIGURE 3: Effect of crude bacterial extracts on cytotoxic activity in control and treated MCF-7 cells. Results are expressed in terms of values representing mean $\pm S D$ where $n=3$ at ${ }^{*} \mathrm{P}=0.05$.

good proton donors and hence can be used as free radical inhibitors. Differential activity of extracts is supposed due to the contribution of different chemical components having varied concentrations of biometabolites. Role of bacterial extracts as antioxidants in terms of DPPH scavenging was established earlier over B. Subtillis, Streptomyces, Virgibacillus, etc. [Figure 2] [27-30].

4.3. MTT Assay. MTT cytotoxicity tests were conducted to identify the anticancer property or cytotoxicity of extract against MCF-7. It reflects a strong cytotoxicity at IC50 value of $64.65 \mu \mathrm{g} \mathrm{ml}$ after an incubation of $48 \mathrm{~h}$. Metabolites with lower IC50 value prove to be efficient in cytotoxicity even at low dose [31]. Active principles of cellular toxicity resides on the bioactive metabolites of the extracts. The present findings corroborate earlier anticancer study of crude extracts against MCF-7 cells and demonstrate a potent cytotoxicity at lower IC50 value. A good cytotoxic activity against $\mathrm{He}$ La cells was found with the application of crude extracts of $B$. thuringiensis isolated from mangrove sediments $[32,33]$. A cell line specific activity of cytotoxicity as noticed in the present study using bacterial extracts is supposed to be due to the presence of secondary metabolites as well as complexity in signal cascade guiding for apoptosis [Figure 3.].

4.4. Nuclear Fragmentation and DNA Fragmentation Assay. Hoechst 33258 is a DNA specific dye which stains chromatin present in nucleus of cell. Nuclear morphology can easily be visualized through this staining method. In this experiment, some hallmarks of apoptosis related to nucleus like nuclear condensation and fragmentation have been observed; nuclear fragmentation analysis further confirms its potential as anticancer compound [Figure 4] [34, 35].

DNA degradation of MCF-7 cells was noticed upon application of ethyl acetate extracts which suggest the potential of extracts as an anticancer agent [Figure 5].

4.5. Western Blotting and Activity Staining of SOD. PI 3K, the direct upstream regulator of ser-threonine kinase Akt, is one of the frequently mentioned targets in human cancer. PI $3 \mathrm{~K}$ phosphorylates phosphatidyl inositol and helps in attachment and activation of second messengers that control cellular activities and properties including proliferation, survival, and motility $[36,37]$. Akt is one of the secondary downstream messenger protein which gets activation upon phosphorylation [38]. Phosphorylation of Akt leads to inhibition of proapoptotic signal as well as increase in antiapoptotic molecule [39]. Analysis through western blotting revealed that crude extract inhibits Akt activity which is noticed through reduced expression of phosphorylated Akt (thr 308) [Figure 7]. Reduced expression of phosphoAkt is expected to correlate with the increased expression of PTEN phosphatase which can maintain the level of Akt at this level [40]. Cell death or apoptosis is triggered by the presence of Reactive Oxygen Species (ROS). In the present study, it has been found that the level of most ubiquitous antioxidant enzyme SOD (superoxide dismutase) (here $\mathrm{Cu}-\mathrm{Zn} \mathrm{SOD}$ ) which catalyzes the conversion/partitioning of superoxide radicals into hydrogen peroxide increased considerably in crude extracts treated cells in contrast to control [Figure 6]. Fragmentation analysis along with activity staining of SOD proves that crude ethyl acetate extract was efficient in killing cancer cells [41]. Earlier findings reported that decrease in Akt level and increase in SOD may be due to enhanced activity of PTEN tumor suppressor [38]. It can be assumed that the triggering factor is the degradation of $\mathrm{NF} \kappa-\mathrm{B}$ which leads to the change in oxidative stress of MCF-7 cells upon treatment of extract [42-44]. Therefore, bacterial extract of Bacillus anthracis obtained from vermicomposting of sludge through the downregulation of Akt helps the cancer cells to take its last breath through nuclear degradation.

\section{Conclusion}

The present study has revealed a new dimension in the organic waste recycling process through vermitechnology with regard to its potential as an incubator of beneficial bacterial assemblages which can positively function and enrich the knowledge base in the field of health science. The ethyl acetate extract of bacteria performs a crucial role in 

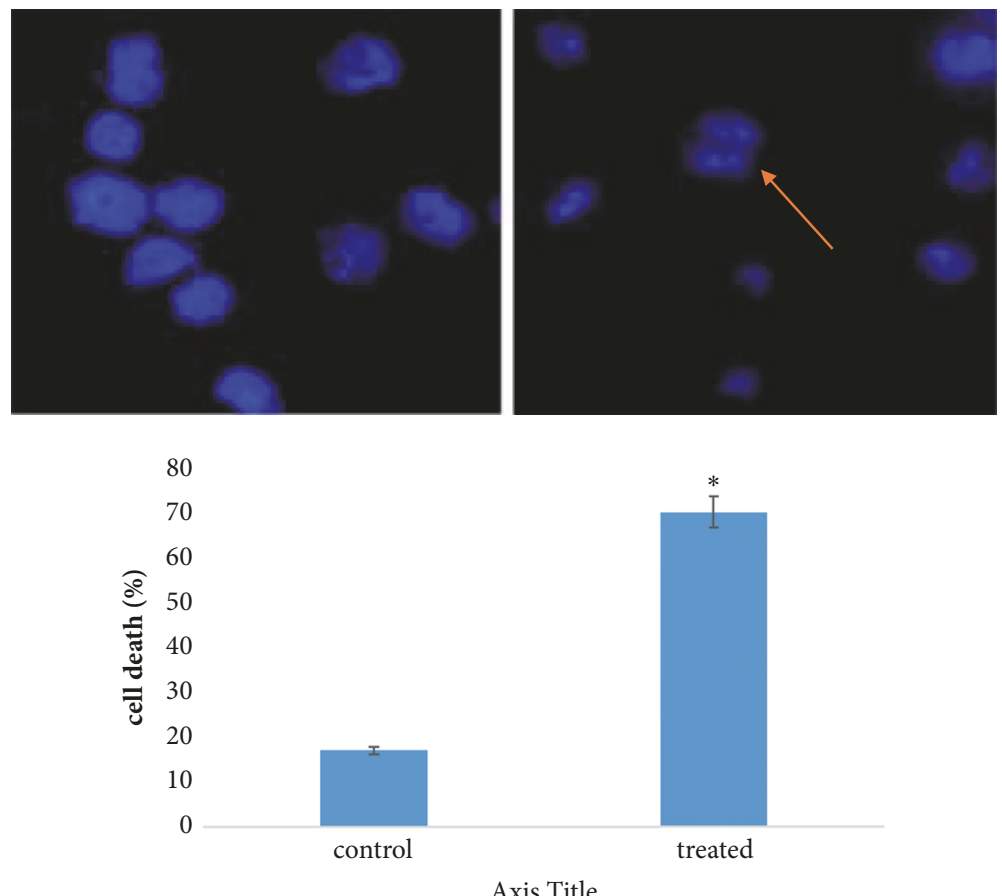

FIGURE 4: Effect of crude bacterial extracts on nuclear fragmentation in control and treated MCF-7 cells. Results are expressed in terms of values representing mean $\pm \mathrm{SD}$ where $\mathrm{n}=3$ at ${ }^{*} \mathrm{P}=0.05$.

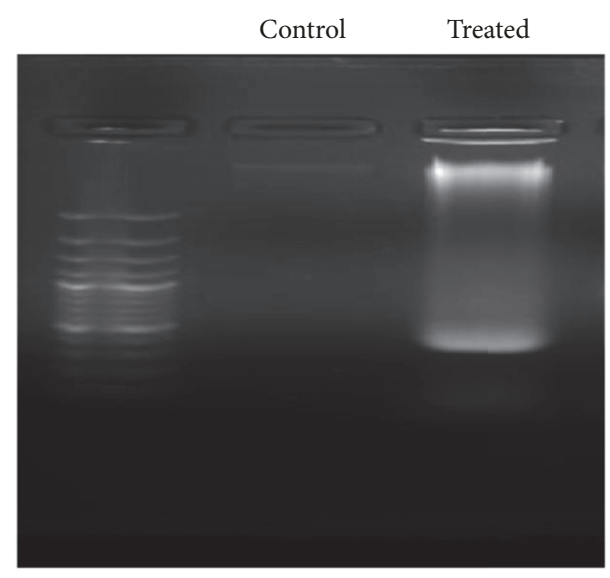

FIGURE 5: DNA fragmentation assay of ethyl acetate extract treated MCF 7 treated cells with respect to control.

controlling the growth of cancer cells. DNA fragmentation and nuclear fragmentation analysis along with MTT assay predict its role as an efficient facilitator of apoptosis. DPPH assay confirms its role as a good antioxidant in comparison with natural antioxidant ascorbic acid. Therefore, the present study can be considered as one of the pioneer studies which emerge a new way to prevent a disease like cancer using bacteria isolated from vermicomposting materials and thereby bring a new vista on multifarious uses of vermitechnology.
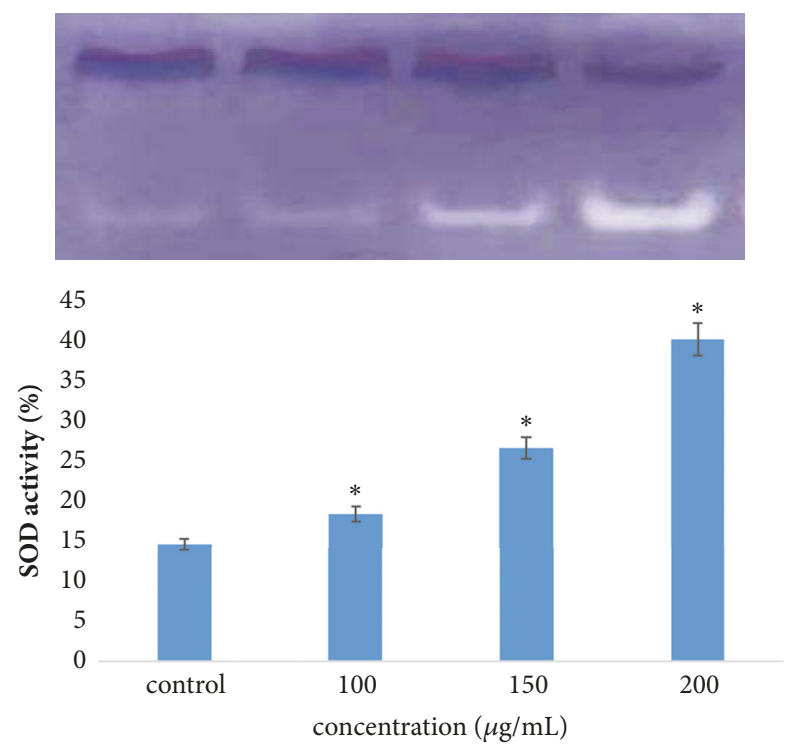

FIGURE 6: Effect of crude bacterial extracts on SOD (superoxide dismutase) in control and treated MCF-7 cells. Results are expressed in terms of values representing mean \pm SD where $n=3$ at ${ }^{*} \mathrm{P}<0.05$.

\section{Data Availability}

The data used to support the findings of this study are available from the corresponding author upon request. 


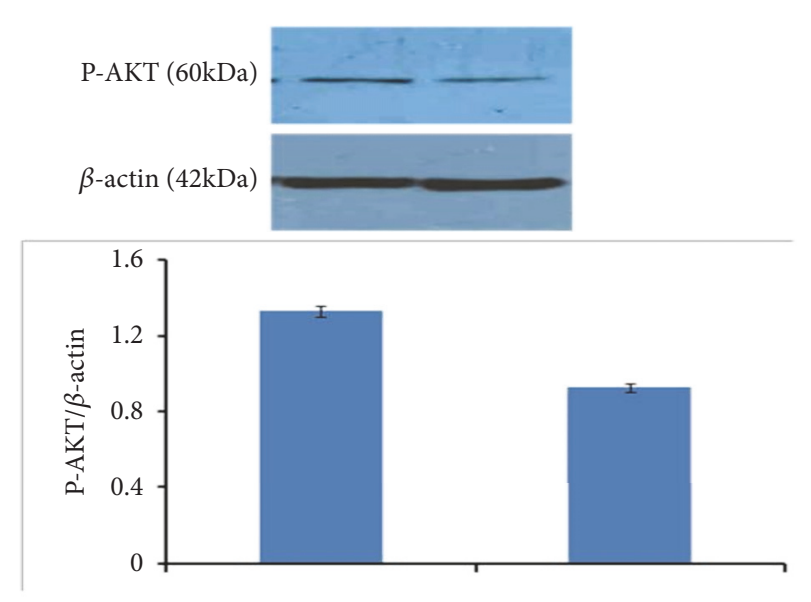

FIgURE 7: Effect of crude extract on activity of Akt in control and treated MCF-7 cells. Results are expressed in terms of values representing mean \pm SD where $n=3$.

\section{Conflicts of Interest}

The authors have no conflicts of interest.

\section{Authors' Contributions}

All the authors participate fully in performing this work. Most of the work like isolation, identification of bacteria, and other analysis was done by Ram Kumar Ganguly. Vermiculture bed maintenance, collection of sample, and writing of manuscript were made by both authors together.

\section{Acknowledgments}

This study acknowledges Vidyasagar University for supporting all sorts of library and laboratory facilities. Special thanks goes to YAAZHXENOMICS (Tamilnadu) for assisting with sequencing purpose.

\section{References}

[1] G. K. Chanda, G. Bhunia, and S. K. Chakraborty, "Evaluation of nutrient status of different organic wastes along with environmental quality in the different phases of vermicomposting by Perionyx excavatus Perrier," Management of Environmental Quality, vol. 21, no. 3, pp. 368-378, 2010.

[2] S. K. Yadav, S. Babu, M. K. Yadav, K. Singh, G. S. Yadav, and Suresh Pal, "A review of organic farming for sustainable agriculture in Northern India," International Journal of Agronomy, vol. 2013, Article ID 718145, 8 pages, 2013.

[3] K. Rajasekar, T. Daniel, and N. Karmegam, "Microbial enrichment of vermicompost," ISRN Soil Science, vol. 2012, Article ID 946079, 13 pages, 2012.

[4] A. A. Ansari, "Worm powered environmental biotechnology in organic waste management," International Journal of Soil Science, vol. 6, no. 1, pp. 25-30, 2011.

[5] K. Raja Sekar and N. Karmegam, "Earthworm casts as an alternate carrier material for biofertilizers: Assessment of endurance and viability of Azotobacter chroococcum, Bacillus megaterium and Rhizobium leguminosarum," Scientia Horticulturae, vol. 124, no. 2, pp. 286-289, 2010.

[6] V. Staedtke, R.-Y. Bai, W. Sun et al., "Clostridium novyi-NT can cause regression of orthotopically implanted glioblastomas in rats," Oncotarget, vol. 6, no. 8, pp. 5536-5546, 2015.

[7] T. Ruby, L. McLaughlin, S. Gopinath, and D. Monack, "Salmonella's long-term relationship with its host," FEMS Microbiology Reviews, vol. 36, no. 3, pp. 600-615, 2012.

[8] A. Jemal, F. Bray, M. M. Center, J. Ferlay, E. Ward, and D. Forman, "Global cancer statistics," A Cancer Journal for Clinicians, vol. 61, no. 2, pp. 69-90, 2011.

[9] R. L. Siegel, D. K. Miller, and A. Jemal, "Cancer statistics 2018," A Cancer Journal for Clinicians, vol. 68, pp. 7-30, 2018.

[10] C. Fung, P. Dinh, S. Ardeshir-Rouhani-Fard, K. Schaffer, S. D. Fossa, and L. B. Travis, "Toxicities associated with cisplatinbased chemotherapy and radiotherapy in long-term testicular cancer survivors," Advances in Urology, vol. 2018, Article ID 8671832, 20 pages, 2018.

[11] N. Bernardes, R. Seruca, A. M. Chakrabarthy, and A. M. Fialho, "Microbial-based therapy of cancer: current progress and future prospects," Bioengineered Bugs, vol. 1, no. 3, pp. 178-190, 2010.

[12] G. Rajauria, A. K. Jaiswal, N. Abu-Gannam, and S. Gupta, "Antimicrobial, antioxidant and free radicalscavenging capacity of brown seaweed Himanthaliaelongata from western coast of Ireland," Journal of Food Biochemistry, vol. 37, no. 3, pp. 322-335, 2013.

[13] G. Immanuel, B. J. Thaddaeus, M. Usha, R. Ramasubburayan, S. Prakash, and A. Palavesam, "Antipyretic, wound healing and antimicrobial activity of processed shell of the marine mollusc Cypraea moneta," Asian Pacific Journal of Tropical Biomedicine, vol. 2, no. 3, pp. S1643-S1646, 2012.

[14] Y. Zhang, Y. Tome, A. Suetsugu et al., "Determination of the optimal route of administration of Salmonella Typhimurium A1-R to target breast cancer in nude mice," Anticancer Reseach, vol. 32, no. 7, pp. 2501-2508, 2012.

[15] M. Momiyama, M. Zhao, H. Kimura et al., "Inhibition and eradication of human glioma with tumor-targeting Salmonella Typhimurium in an orthotopic nude-mouse model," Cell Cycle, vol. 11, no. 3, pp. 628-632, 2012.

[16] R. K. Ganguly and S. K. Chakraborty, "Assessment of microbial roles in the bioconversion of paper mill sludge through vermicomposting," Journal of Environmental Health Science and Engineering, 2018.

[17] S. Garcha, N. Verma, and S. K. Brar, "Isolation, characterization and identification of microorganisms from unorganized dairy sector wastewater and sludge samples and evaluation of their biodegradability," Water Resources and Industry, vol. 16, pp. 1928, 2016.

[18] A. Dereeper, V. Guignon, G. Blanc et al., "Phylogeny.fr: robust phylogenetic analysis for the non-specialist," Nucleic Acids Research, vol. 36, pp. W465-W469, 2008.

[19] M. L. Vijaya Kumar, B. Thippeswamy, and P. Vasanth Raj, "Cytotoxicity and anticancer studies of Bacillus cereus and Bacillus pumilus metabolites targeting human cancer cells," Applied Biochemistry and Microbiology, vol. 50, no. 6, pp. 619623, 2014.

[20] G. C. Yen and H. Y. Chen, "Antioxidant activity of various tea extracts in relation to their antimutagenicity," Journal of Agricultural and Food Chemistry, vol. 43, no. 1, pp. 27-37, 1996.

[21] J. S. Garcia, P. L. Gratão, R. A. Azevedo, and M. A. Z. Arruda, "Metal contamination effects on sunflower (Helianthus annuus 
L.) growth and protein expression in leaves during development," Journal of Agricultural and Food Chemistry, vol. 54, no. 22, pp. 8623-8630, 2006.

[22] S. Ravikumar, M. Fredimoses, and M. Gnanadesigan, "Anticancer property of sediment actinomycetes against MCF-7 and MDA-MB-231 cell lines," Asian Pacific Journal of Tropical Biomedicine, vol. 2, no. 2, pp. 92-96, 2012.

[23] D. Zurek-Biesiada, S. Kedracka-Krok, and J. W. Dobrucki, "UVactivated conversion of Hoechst 33258, DAPI, and Vybrant DyeCycle fluorescent dyes into blue-excited, green-emitting protonated forms," Cytometry Part A, vol. 83, no. 5, pp. 441-451, 2013.

[24] C. N. M. Ribeiro, L. C. Peres, J. M. PinaNeto, and J. Med, "DNA extraction and quantification from touch and scrape preparations obtained from autopsy liver cells," Brazilian Journal of Medical and Biological Research, vol. 37, no. 5, pp. 635-642, 2004.

[25] S. M. Dutta, S. B. Mustafi, S. Raha, and S. K. Chakraborty, "Biomonitoring role of some cellular markers during heat stress-induced changes in highly representative fresh water mollusc, Bellamya bengalensis : Implication in climate change and biological adaptation," Ecotoxicology and Environmental Safety, vol. 157, pp. 482-490, 2018.

[26] S. Kato, K. Shindo, H. Kawai, M. Matsuoka, and J. Mochizuki, "Studies on free radical scavenging substances from microorganisms III. Isolation and structural elucidation of a novel free radical scavenger, resorstatin," The Journal of Antibiotics, vol. 46, no. 6, pp. 1024-1026, 1993.

[27] S. Hajihashemi and J. M. C. Geuns, "Antioxidant and biochemical evaluation of metabolites from the marine bacteria Vrigibacillus sp. associated with the sponge Callyspongiadiffusa," Free Radicals and Antioxidants, vol. 3, pp. 34-41, 2013.

[28] M. Thenmozhi, S. Sindhura, and K. Kannabiran, "Characterization of antioxidant activity of Streptomyces species VITKK3 isolated from Puducherry Coast," Journal of Advanced Scientific Research, vol. 1, pp. 46-52, 2010.

[29] E. M. Tanvir, M. S. Hossen, M. F. Hossain et al., "Antioxidant properties of popular turmeric (Curcuma longa) varieties from Bangladesh," Journal of Food Quality, vol. 2017, Article ID 8471785, 8 pages, 2017.

[30] S. N. Syed Abdul Rahman, N. Abdul Wahab, and S. N. Abd Malek, "In vitro morphological assessment of apoptosis induced by antiproliferative constituents from the rhizomes of Curcuma zedoaria," Evidence-Based Complementary and Alternative Medicine, vol. 2013, Article ID 257108, 14 pages, 2013.

[31] M. Maeda, E. Mizuki, M. Hara et al., "Isolation of Bacillus thuringiensis from intertidal brackish sediments in mangroves," Microbiological Research, vol. 156, no. 2, pp. 195-198, 2001.

[32] R. Ramasubburayan, S. Sumathi, D. Magi Bercy, G. Immanuel, and A. Palavesam, "Antimicrobial, antioxidant and anticancer activities of mangrove associated bacterium Bacillus subtilis subsp. subtilis RG," Biocatalysis and Agricultural Biotechnology, vol. 4, no. 2, pp. 158-165, 2015.

[33] F. Ourique, M. R. Kviecinski, K. B. Felipe et al., "DNA damage and inhibition of akt pathway in MCF-7 cells and ehrlich tumor in mice treated with 1,4-naphthoquinones in combination with ascorbate," Oxidative Medicine and Cellular Longevity, vol. 2015, Article ID 495305, 10 pages, 2015.

[34] F. Namvar, H. S. Rahman, R. Mohamad et al., "Apoptosis induction in human leukemia cell lines by gold nanoparticles synthesized using the green biosynthetic approach," Journal of Nanomaterials, vol. 2015, Article ID 642621, 10 pages, 2015.
[35] M. M. Kosanić, B. R. Ranković, and T. P. Stanojković, "Antioxidant, antimicrobial and anticancer activities of three Parmelia species," Journal of the Science of Food and Agriculture, vol. 92, no. 9, pp. 1909-1916, 2012.

[36] N. Xu, Y. Lao, Y. Zhang, and D. A. Gillespie, "Akt: A doubleedged sword in cell proliferation and genome stability," Journal of Oncology, 2012.

[37] A. Kumar, V. Rajendran, R. Sethumadhavan, and R. Purohit, "AKT kinase pathway: a leading target in cancer research," The Scientific World Journal, vol. 2013, Article ID 756134, 6 pages, 2013.

[38] Y. Liu, J. Y. Lv, J. F. Shi et al., "Targeting the raft-associated akt signaling in hepatocellular carcinoma," BioMed Research International, vol. 2014, Article ID 836025, 9 pages, 2014.

[39] S. Matsuda, M. Kobayashi, and Y. Kitagishi, "Roles for PI3K/ AKT/PTEN pathway in cell signaling of nonalcoholic fatty liver disease," ISRN Endocrinology, vol. 2013, Article ID 4724327, 7 pages, 2013.

[40] H. Akca, A. Demiray, M. Aslam, I. Ackibas, and O. Tokgen, "Tumour suppressor PTEN enhanced enzyme activity of GPx, SOD and catalase by suppression of PI3K/AKT pathway in nonsmall cell lung cancer cell lines," Journal of Enzyme Inhibition \& Medicinal Chemistry, vol. 28, 2013.

[41] P. Huang, L. Feng, E. A. Oldham, M. J. Keating, and W. Plunkett, "Superoxide dismutase as a target for the selective killing of cancer cells," Nature, vol. 407, no. 6802, pp. 390-395, 2000.

[42] T. Henkel, T. Machleidt, I. Alkalay, M. Krönke, Y. Ben-Neriah, and P. A. Baeuerle, "Rapid proteolysis of $\mathrm{I} \kappa \mathrm{B}-\alpha$ is necessary for activation of transcription factor NF- $\kappa \mathrm{B}$," Nature, vol. 365, no. 6442, pp. 182-185, 1993.

[43] C. T. D'Angio and J. N. Finkelstein, "Oxygen regulation of gene expression: a study in opposites," Molecular Genetics and Metabolism, vol. 71, no. 1-2, pp. 371-380, 2000.

[44] N. Li and M. Karin, "Is NF- $\kappa$ B the sensor of oxidative stress?" The FASEB Journal, vol. 13, no. 10, pp. 1137-1143, 1999. 


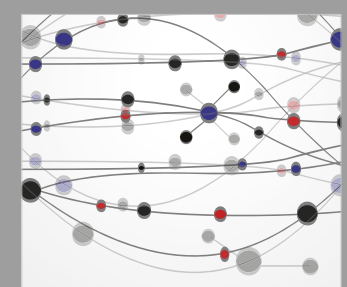

The Scientific World Journal
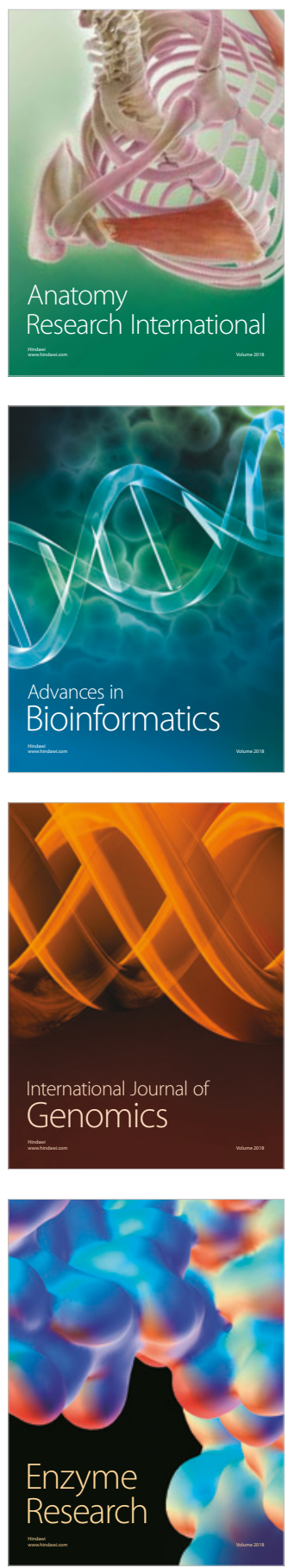
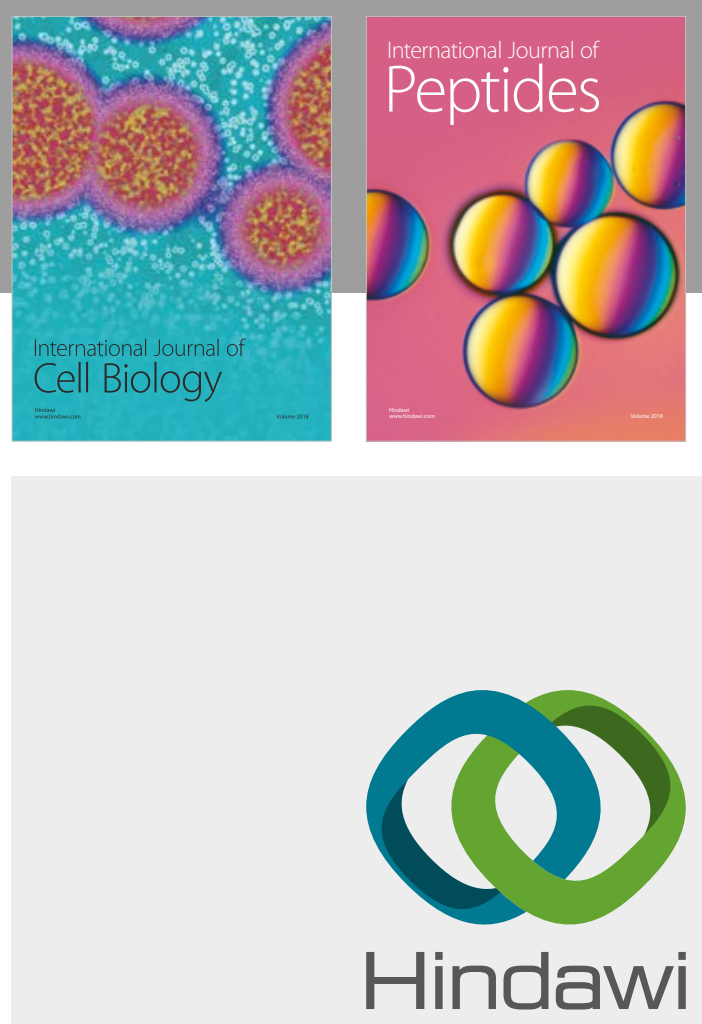

Submit your manuscripts at

www.hindawi.com
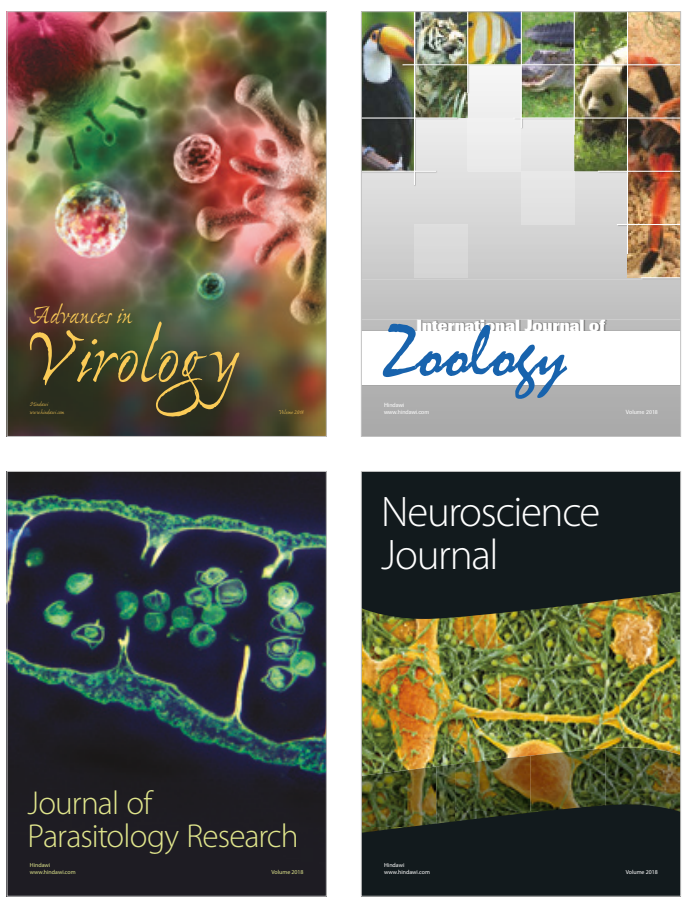
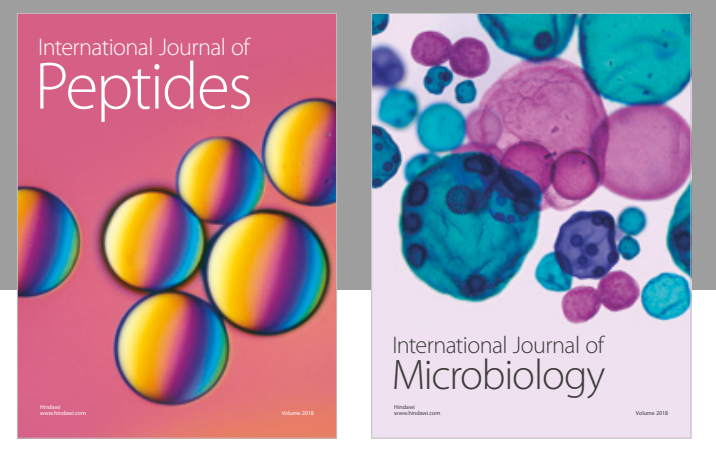

nternational Journal of Microbiology
Journal of
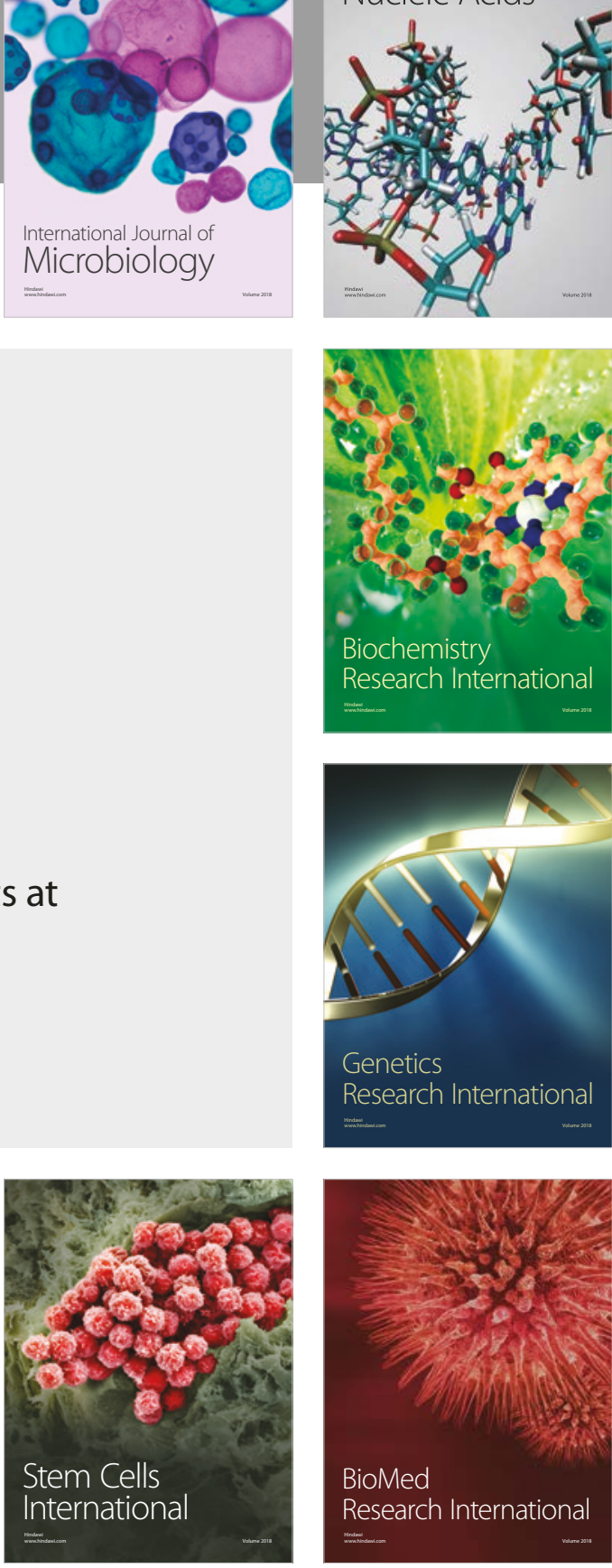
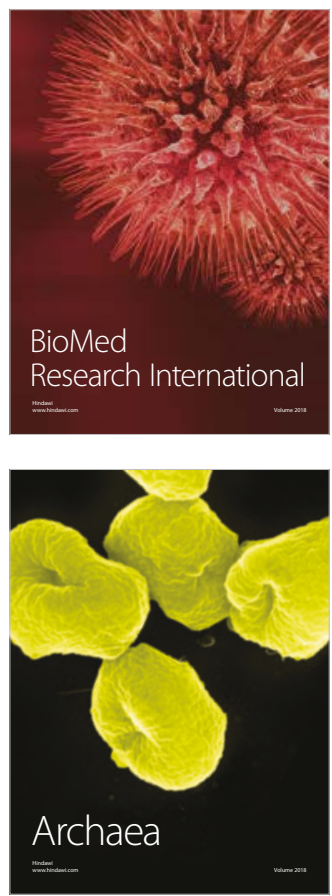